\begin{tabular}{|l|l|l||}
\hline \multicolumn{2}{|c|}{ PublisherInfo } \\
\hline \hline PublisherName & $:$ & BioMed Central \\
\hline \hline PublisherLocation & $:$ & London \\
\hline \hline PublisherImprintName & $:$ & BioMed Central \\
\hline \hline
\end{tabular}

\title{
Ancient introns
}

\begin{tabular}{|l|l|l||}
\hline \multicolumn{2}{|c|}{ ArticleInfo } \\
\hline \hline ArticleID & $:$ & 4250 \\
\hline \hline ArticleDOI & $:$ & $10.1186 /$ gb-spotlight-20011113-01 \\
\hline \hline ArticleCitationID & $:$ & spotlight-20011113-01 \\
\hline \hline ArticleSequenceNumber & $:$ & 321 \\
\hline \hline ArticleCategory & $:$ & Research news \\
\hline ArticleFirstPage & $:$ & 1 \\
\hline \hline ArticleLastPage & $:$ & 2 \\
\hline \hline & & RegistrationDate : 2001-11-13 \\
ArticleHistory & $:$ & OnlineDate \\
\hline \hline ArticleCopyright & $:$ & BioMed Central Ltd2001 \\
\hline \hline ArticleGrants & $:$ & \\
\hline \hline ArticleContext & $:$ & 130592211 \\
\hline \hline
\end{tabular}




\section{Jonathan B Weitzman}

Email: jonathanweitzman@hotmail.com

The origins of introns and their evolutionary role remain unclear. In the November 6 Proceedings of the National Academy of Science, Fedorov et al. describe the use of a computer program, called INTRONMAP to present evidence for the existence of ancient introns (Proc Natl Acad Sci USA 2001, 98:13177-13182). They used the program to map intron positions onto homologous genes encoding proteins for which the three-dimensional structure is known. They applied the program to 665 nonredundant protein sequences in the Protein Data Bank and mapped over 8,000 introns. The result was a correlation of phase-zero introns with module boundaries in proteins, corresponding to ancient conserved regions (ACR). There was no correlation for phase-one or phase-two positions, or for nonACR proteins (which presumably represent 'modern' genes).

\section{References}

1. What introns have to tell us: hierarchy in genome evolution.

2. Proceedings of the National Academy of Science, [http://www.pnas.org]

3. INTONMAP, [http://mcb.harvard.edu/gilbert/INTRONMAP]

4. Protein Data Bank, [http://www.rcsb.org/pdb/] 